
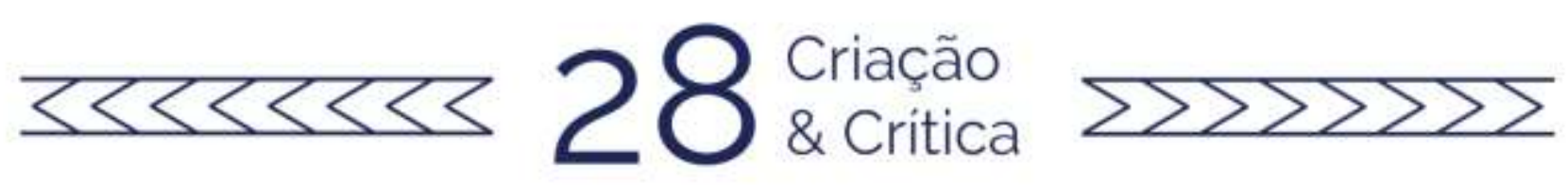

MEWEMWWM

Maria Clara Contrucci ${ }^{1}$

\title{
Apresentação
}

Este vídeo foi produzido em resposta a uma provocação da Pós-Graduação Lato Sensu em Escritas Performáticas, da PUC-Rio, no ano de 2020. Nele, reflito a relação entre corpo, gesto, imagem e escrita. Interesso-me pela possibilidade de comunicar por meio das mãos. O gesto me parece se configurar como uma espécie de miniatura do pensamento. Uma miniatura no sentido de que podemos elaborar e coreografar conceitos e ideias usando apenas as nossas mãos, como códigos, assim como fazemos com as palavras e as letras. As mãos carregam esse caráter de veículo da comunicação não-verbal, assim como da comunicação escrita. Usamos nossas mãos e dedos também para escrever. Gosto de pensar nessa capacidade das mãos de sintetizar ideias e estruturas mais amplas. Pensar 0 corpo como essa matéria-prima da linguagem, que contém infinitas possibilidades. É através do corpo que recebemos o mundo em torno de nós, e me parece ser no corpo que qualquer linguagem se inicia e se organiza. A partir dele podemos produzir novas linguagens, despertar novos sentimentos, novos caminhos.

Quis pensar a ideia de encontro através das minhas mãos. Como poderia representar, produzir um encontro com as mãos e com os dedos? Comecei a experimentar e encontrei no gesto de estender três dedos algumas possibilidades. Percebi que esse gesto poderia representar também graficamente uma letra. Essa experimentação resultou no vídeo, que é um jogo de possibilidades semânticas geradas a partir desse gesto de três dedos estendidos em uma correspondência entre o corpo e a letra. $O$ gesto pode vir a nos lembrar do número três, ou também a letra $M, W$ ou $E$, dependendo da direção que é visto.

Compreendo encontro como o momento em que duas ou mais partes (pessoas, conceitos, palavras, imagens) estáveis e reconhecíveis se esbarram e, a partir daí, são capazes de produzir algo novo, algo de fato ainda desconhecido. No vídeo, $M E$ e $W E$, que são as palavras para 'eu' e 'nós' na língua inglesa, apresentam-se como as possíveis palavras a serem formadas por uma mesma grafia, reveladas pelo gesto. Um gesto que fala da língua, do gesto e que retorna para a língua, e assim por diante, em uma série de reenvios.

As palavras $M E$ e WE têm essa grafia curiosa: para escrevê-las é preciso a mesma matéria, o mesmo desenho, traço, gesto. Usar uma mesma matéria para falar de eu e nós me faz pensar sobre o que realmente define o encontro. Encontrar o outro é também de alguma

1 Pós-graduação no programa Escritas Performáticas no Departamento de Letras da PUC-Rio. Contato: mariaclaracontrucci@gmail.com 

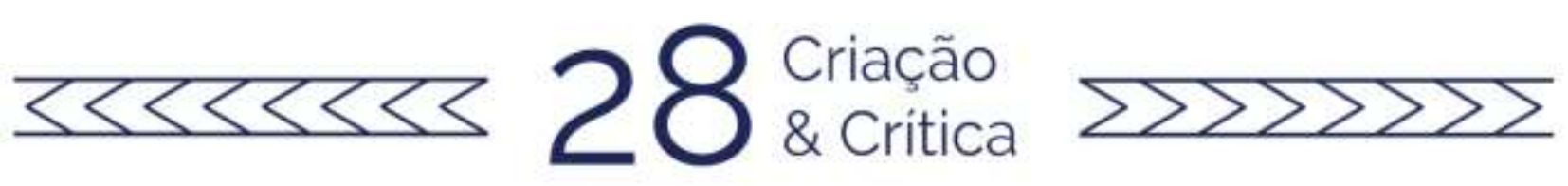

forma "girar" em torno de si mesmo, se enxergar em outras direções e se modificar a partir disso. À medida que as mãos se aproximam, as letras giram em outras direções e formam um novo símbolo ou letra ao se encontrarem, produzindo essa terceira e nova possibilidade.

\section{Ficha técnica:}

Título: MEWEMWWM

Mídia: Vídeo

Ano: 2020

Performance, filmagem e edição: Maria Clara Contrucci

Disponível em: <https://vimeo.com/472420724>.

Recebido em: 21/11/2020

Aceito em: 21/11/2020

Referência eletrônica: CONTRUCCI, Maria Clara. MEWEMWWM. Criação \& Crítica, n. 28, p., dez. 2020. Disponível em: <http://revistas.usp.br/criacaoecritica>. Acesso em: dd mmm. aaaa. 